\title{
Children's Labour as a Risky Pathways to Resilience: Children's Growth in Contexts of Poor Resources
}

\section{Trabalho Infantil como um Caminho em Direção à Resiliência Marcado por Riscos: O Crescimento de Crianças e Adolescentes em Contextos Pobres em Recursos}

\author{
Renata Maria Coimbra Libório*, a \& Michael Ungar ${ }^{\mathrm{b}}$ \\ ${ }^{a}$ Universidade Estadual Paulista Júlio de Mesquita Filho/Brasil \\ ${ }^{b}$ Dalhousie University/Canadá
}

\begin{abstract}
In this paper we explore children's labor as a complex phenomenon encompassing risk factors on one hand and possible positive outcomes on the other. Based on the theory of resilience and on literature review that details children's own experiences of work, we show that children who are inserted in environments which are poor in social and physical resources may report labor as pathways to ensure their own resources to overcome adversity. Understanding children's subjective accounts of their experience permits us to see children's labor as a culturally-embedded construction. Though exploitation of children is not in the best interest of children, there is evidence that children use whatever opportunities are available, including labor, to search for the resources they need and negotiate for an identity as resilient. Implications for public policies and practices are discussed.

Keywords: Children and Adolescents; Labor; Resilience

Resumo

Nesse artigo, analisamos a questão do trabalho infantil como um fenômeno complexo, englobando fatores de risco por um lado e possíveis resultados positivos por outro. Baseados na teoria da resiliência e a partir de uma revisão de literatura, centrada em pesquisas que analisam a própria experiência de crianças sobre o trabalho desenvolvido, mostramos que quando inseridos em ecologias socialmente e fisicamente pobres em recursos, crianças associam sua experiência de trabalho como um caminho para assegurar recursos próprios para superação de adversidades. A compreensão de aspectos subjetivos da experiência de crianças trabalhadores nos permite considerar o trabalho como uma construção culturalmente embasada. Apesar da exploração de crianças não se configurar como o melhor para elas, há evidências de que elas usam quaisquer oportunidades disponíveis, incluindo o trabalho, para navegar em busca de recursos que necessitam e negociam por uma identidade associada à resiliência. Implicações para políticas públicas e intervenções também são discutidas.

Palavras-chave: Crianças e Adolescentes; Trabalho; Resiliência.
\end{abstract}

When understood from the perspective of children ${ }^{1}$ themselves, aspects of child labour and work may contribute to well-being when alternative paths to psychosocial development are under-resourced. In an effort to broaden the discourse regarding both children's labour (forced exploitation that places children at extreme risk) and children's work (less coercive forms of child enga-

\footnotetext{
*Address: Rua Conceição Lima da Silva, 140, Residencial Central Park, Presidente Prudente, SP, Brasil, CEP 19060 560. Tel.: (18) 3229 5388, ramal 5529; Fax: (18) 32226343. E-mail: coimbralibor@uol.com.br

Acknowledgements: The authors gratefully acknowledge the support of Program University Estadual Paulista (UNESP)/ Banco REAL which provided support for the first author 's post-doctoral research at Dalhousie University.

${ }^{1}$ In this paper we are using the definition by United Nation Convention on the Rights of the Child (1990), in which "child means every human being below the age of 18 years old" (article 1)
}

gement in the means of production), we will examine children's own understanding of their labour and work experiences. Our goal is move towards a fuller appreciation of children's work experiences and identification of viable alternatives to exploitive forms of children's work and labour. Research with children has shown that not all children appreciate efforts to emancipate them from their roles as child labourers, soldiers or workers (International Union of Anthropological and Ethnological Sciences, 2002). Children in resource poor contexts may offer accounts of their work as formative developmental experiences that help them secure valuable psychosocial resources necessary to their future growth (Ungar, 2005). We emphasize that such gains are an unfortunate situation, with children's participation in work-related activities being a poor substitute for more socially acceptable means of participation that bring with them positive outcomes associated with resilience. 
Libório, R. M. C. \& Ungar, M. (2010). Children's Labour as a Risky Pathways to Resilience: Children's Growth in Contexts of Poor Resources.

To organize our discussion, we will gather the research on children's experiences of work under topics relevant to the study of resilience. Research has shown that resilience is more than just individual children beating the odds stacked against them. Resilience also depends on having those odds changed so that positive development amid exposure to multiple risk is facilitated and well resourced (Seccombe, 2002). A contextualized understanding of resilience suggests that resilience is more than the individual's capacity to thrive despite exposure to adversity. It is also a quality of the child's surroundings. Elsewhere, Ungar (2008) has defined resilience as a social ecological construct:

In the context of exposure to significant adversity, whether psychological, environmental, or both, resilience is both the capacity of individuals to navigate their way to health-sustaining resources, including opportunities to experience feelings of well-being, and a condition of the individual's family, community and culture to provide these health resources and experiences in culturally meaningful ways. (p. 225).

A study conducted by Ungar and his colleagues to determine the relevance of this definition to children globally showed that children negotiate for the best possible resolution of seven tensions (a dynamic interpretation of protective factors) in their lives (Ungar et al., 2007). Children who say they are thriving while exposed to acute and chronic stressors must satisfy their need for: identity, relationships, access to material resources, social cohesion (including religious affiliation), power and control, social justice, and cultural adherence (the seven tensions). Because Ungar et al. (2007) looked across cultures and contexts, their findings were less deterministic than most studies of resilience. No singular pattern of successful development was found to be any better than any other raising questions regarding the efficacy of atypical developmental paths when opportunity structures limit children's future chances to secure the resources necessary for mental and physical health. Each of these seven tensions was a problem children resolved by maximizing the utility of all the resources available to them in social and physical ecologies where there were serious threats to their well-being. In this way, behaviors that might be maladaptive in resource rich environments (such as violence) might serve protective functions in environments where the child's development was in danger (gang violence may, in some contexts, protect children from further abuse-see Taylor et al., 2002). Through detailed narratives collected in eleven countries, Ungar et al. (2007) showed that involvement with street youth can secure supportive relationships; life in an orphanage can provide a child with a parentified identity as caregiver in the absence of the child's own caregiver; dropping out of school can buffer threats to one's self-concept when school has failed to make a child feel competent; and becoming an entrepreneur can provide a teenage mother access to financial independence better than education in contexts where education is expensive or there is a gender bias against girls' participation. It is this socially and contextually relevant understanding of pathways to resilience which will be used as our lens through which to review the findings of a number of studies that have captured children's accounts of their labour and work. We will show how children's accounts of their experience compete with adultocentric understandings of these same phenomena.

\section{Adult Constructions of Childhood}

Typically, our understanding of child labour and work reflects what Bourdillon (2006) has termed a western notion of childhood. Bourdillon argues that in western cultures, childhood is wrongly portrayed as a developmental period characterized by learning and leisure, a time to be cared for by others, and a period during which individuals should be protected against violence and exploitation, even if this means denying them responsibilities associated with employment. Any other experience during childhood is thought to result in their formative years being "stolen" or "lost". This understanding of childhood naively structures the world into binary categories (man and woman, child and adult) with bias towards one set of behaviours as developmentally beneficial. Seen through the eyes of western adults, children are:

Diminished. Children are evaluated as less than perfect adults. They lack adult capacities and strengths and are therefore cognitively, morally and physically incomplete or failed adults (Pinto \& Sarmento, 1997).

Infantilized. Children are distinguished as both ontologically and phylogenetically less than adults. Their competence is misjudged. They are thought to be lesser evolved and incapable of exercising good judgement (Lesko, 2001).

Fetishized. Children are smaller versions of adults who are constructed as extensions of adults' own selves. Children become idealized for their innocence, objectified through child beauty pageants, or admired for their uncorrupted selves as evidenced in the child virtuoso, child actor, or sports star who achieves perfection without adult failings (Quart, 2006).

Bourdillon (2006) suggests instead that children's experiences are multiple, varying according to specific material, economic and cultural conditions, and different for children depending on their age, gender and capabilities. Seen this way, children may preserve their right to protection and support while acknowledging that a continuum exists between children's worlds and those of adults, with children "gradually moving into the activities of the adults as their competence develops and opportunities arise" (p. 1202). This understanding of childhood may incorporate work as an activity that plays an important role during a child's development while young people mature. Childhood, therefore, is better conceptualized as a constructed reality that varies across time 
and context. The tendency by adult elites, whose contributions to popular discourse exert greater influence than that of children, is to construct children and childhood today as separate from adults and adulthood (Howe, 2007; Lesko, 2001). While the differences between children and adults are obvious, this act of exclusion and differentiation through discourse may overlook children's rights to participation and their immense potential for contribution to the welfare of others. Viewed differently, children may be seen as agentic beings who have rights onto themselves. While developmentally still growing, their intrinsic worth is equal to every other individual (adult) and they should be provided with opportunities for participation equal to their capacity. This perspective is embodied in the United Nations (UN) Convention on the Rights of the Child (1990):

State Parties shall assure to the child who is capable of forming his or her own views the right to express those views freely in all matters affecting the child, the views of the child being given due weight in accordance with the age and maturity of the child. (article 12, p. 4).

Current constructions of the child as innocent (fetishized) and vulnerable (infantilized or diminished) disadvantage already marginalized children who may negotiate through work adequate transitions to adulthood (see Ungar, 2004). Discursively, the study of children's labour and work has struggled to privilege children's own voices in discussions of their experience. While there are certainly aspects of children's exploitation through labour that require intervention and remediation, children's own accounts of these experiences are often at odds with what adults say is in the child's best interest (Anyango-Kivuva, 2006; Mapedzahama \& Bourdillon, 2000; Rubenson, 2005).

More equitable representation in the social discourse that defines the experience of working children demonstrates nuanced arguments for children's right to work in non-exploitive settings (congruent with the principles of the U.N.C.R.C.). Arguably, definitions of child labour have become too limiting, ignoring both the empirical evidence that shows children's work helps vulnerable young people survive (Bass, 2004; Invernizzi, 2003; Kielland \& Tovo, 2006; Mizen, Pole, \& Bolton, 2001; Montgomery, 1998; Moshin, 2002), and children's own subjective accounts that tell how aspects of well-being are enhanced through their participation in labour market activities (Hugerland, Liebel, Lisecke, \& Wilznuth, 2007; Invernizzi \& Tome, 2007) and domestic activities in their own homes (Libório \& Pessoa, 2008). Childhood is a social construct that either promote or discourage children being defined as social actors with the power to influence the age at which they assume adult roles. The idea of children as less agentic than adults and in need of care and protection places children within unbalanced power relationships and unduly under the subordination of adults. Children who are marginalized by their ethnoracial background, economic status, or other individual and social traits, are doubly disadvantaged within a discourse of childhood that delays emancipation (Pinto \& Sarmento, 1997). In fact, we have tended to ignore the evidence from cross-cultural studies of children which has documented their immense capacities to cope with life stress when required (Annan, 2007; Baldwin, 2006; Botelho, Silva, Kassab, \& Leite, 2008; Cortes \& Buchanan, 2007; Kidd \& Davidson, 2007; Libório, 2003; Perez-Carreon, 2006).

Accounting for cultural differences has been part of the challenge when trying to understand children's own work experiences. Different cultures arbitrarily decide the age at which work by children is exploitive. The nature of the work children do and the degree to which it is thought to exploit also varies by context (for example, rural farm labour vs. urban factory work; a poor child's participation in domestic chores vs. a rich child's internship at a summer camp). Though there is much evidence of arbitrariness in decisions regarding what kinds of work exploit children, there are many aspects of child labour that are near universal in their description as being contrary to children's well-being. These include child sexual exploitation, debt bondage, armed conflict, and drug production and trafficking by children (International Labour Organization [ILO], 1999), all of which are condemned by most governments. Many other forms of children's work, however, remain controversial depending on how childhood itself is socially constructed and children's capacities and deficits are understood. For example, domestic labour for ten-year-olds, or apprenticeships in the trades for fourteen-year-olds exist within this contested territory in which definitions of child labour and children's work are variably constructed.

\section{Children's Discourses}

Seen from the point of view of resilience in resource poor environments, children's labour and work may bring experiences of participation, contribution and even empowerment. Support for this point of view comes from an unlikely source, the U.N.C.R.C. which advocates for children's participation in the decisions affecting them. It says that children need both protection and opportunities to show responsibility for themselves and others. In the discourse that determines whether labour and work are wholly good, bad or both, there is evidence that children themselves find through their participation in the market economy means of contributing to their own welfare and that of others (Anyango-Kivuva, 2006; Bourdillon, 2006; Invernizzi \& Tome, 2007; M. Leonard, 2004; Libório \& Pessoa, 2008; Liebel, 2007a, 2007b; Montgomery, 1998; Rubenson, 2005; Woodhead, 1999).

In situations where children are exploited, but where there are few, if any, alternative resources besides labour to resolve the seven tensions named by Ungar et al. (2007), even exploitive "employment" (e.g., being indentured) may bring some rewards. Figure 1 summarizes our understanding of the orthogonal relationship between 
Libório, R. M. C. \& Ungar, M. (2010). Children's Labour as a Risky Pathways to Resilience: Children's Growth in Contexts of Poor Resources.

the quality of children's labour and work (exploitation vs. contribution) and the nature of the child's experience that participation brings. While it is easier to conceive of the child who experiences negative outcomes from exploitive forms of labour, a child's experience of work is a co-construction. The values and beliefs held by his or her family and community, and the nature of the tasks demanded, will influence the child's perception of the labour experience. For example, a child growing up in a well-resourced middle-class home who is asked to make a contribution through domestic work (household chores) may experience that work as demeaning if she sees herself as capable of making a contribution in other more widely valued ways (e.g., a job at a trendy clothing store). In other words, we understand that the objective analysis of the exploitative context, evaluated through the perspective of an outsider (grounded in the universal conception of childhood and children's rights), must be countered by the subjective and singular meaning attributed by children themselves to their experience.

Figure 1: Children's Subjective Experience of Work

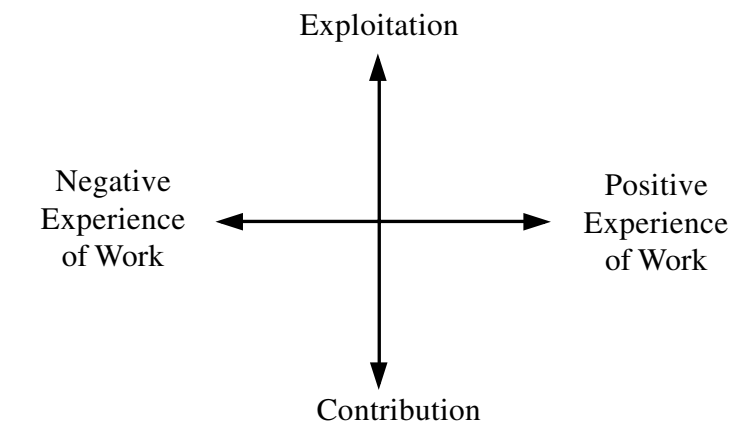

Figure 1. Children's subjective experience of work

According to Martinez (2001), children's labour and work occur within a relational sphere in which psychological resources such as positive acknowledgement (even at minimum levels) may be secured. Similarly, Woodhead (2004) explains that the nature of the work children do is not categorically good or bad, but must be viewed for its social value, how well it meets the expectations by others of the child, how well the child's developmental needs are met through the work, whether the work secures the attention of mentors for the child, and the extent to which positive growth advanced through the work mediates the potential harm exploitive employment can cause. The meaning working children co-construct with adults of their work experience is necessarily negotiated, resulting in different ways that children will both feel about what they do and the attributions they make (whether they see their work as exploitive or as contribution).

\section{The Connection Between Resilience, Labour and Work}

As has been argued above, the nature of children's experience of labour and work is heterogeneous, the result of their subjectivity. Resilience is not just the capacity of the child to thrive under adversity, but also a measure of the capacity of the child's social and physical ecologies to provide the resources necessary to thrive in ways meaningful to the child. In contexts where there are limited social and educational opportunities to achieve a higher status and transition towards a more mature standing as a contributing member of one's family or community, work offers an illegitimate means to achieving positive psychosocial growth. In such situation, we can say that children show "hidden resilience" (Ungar, 2004), a pathway to successful development that is socially discordant.

This subject-oriented perspective can, however, tumble into the abyss of relativism unless one distinguishes child work and contribution from harsh and exploitive child labour. Though social constructionists may argue for the privileging of multiple discourses, there are aspects of social discourse which function as universals for the sake of individual and collective well-being. These "universal by consent" (P. Leonard, 1997) principles allow us to assert that at times the risks posed to children outweigh any reasonable expectation of the gains made. The U.N.C.R.C. is indicative of the near universality of some such beliefs about children (all but two countries, the United States and Somalia, are signatories), including the desire to protect them. Beyond the physical threats of exploitation (violence, disease, death), extreme forms of child labour (like sexual exploitation) present compounded risks such as marginalization, stigma, extreme poverty, and the breakdown of nurturing relationships that cause a significant negative psychosocial impact on children`s lives (Woodhead, 2004). For children who argue that their experience of child labour is related to some positive outcomes (Anyango-Kivuva, 2006; Cortes \& Buchanan, 2007; Li, 2007; Mapedzahama \& Bourdillon, 2000; Montgomery, 1998; Offit, 2003; Rubenson, 2005), we would argue that they have made the best of a bad situation (Berge, 2007) and would likely accrue greater benefit from an alternative experience of work and contribution if one was made available.

A review of the literature which has studied children's experiences of labour and work highlights this balance between positive and negative outcomes. Risks associated with labour and work may be loosely gathered under the headings structural, relational, and personal (see Tables 1, 2 and 3). Structural, or systemic, risks include the exploitation of children as workers within the global labour market. Employers (a misnomer in instances of child labour when the child is abducted or indentured to perform tasks for the economic and social benefit of others) maximize their advantage in the marketplace by minimizing the cost of production through child labour. 
Their low subsistence costs, unregulated employment, lack of caregiver oversight, and children's general lack of agency to control the means of production, disadvantage children in negotiations for a sustainable level of compensation for their labour and safe working conditions. Structural consequences to child labour and work can also include stigmatization. The working child may be socially ostracized by peers, or be devalued within public discourse which labels the child and the child's family as dysfunctional.

Relational aspects of labour and work skew relationships in ways that may threaten psychosocial development. Removal from family, sexually or physically abusive behaviour towards the child, and social isolation, cause children to lose continuity in attachments, or create traumatic reactions to normal aspects of psychological functioning (such as attachment, touch, and sexual development).

At the level of the individual child, personal risk factors associated with labour and work may compromise the child's self-concept, as when emotionally and physically abusive contexts undermine the child's positive sense of self. Individual threats may also include illiteracy. Each risk undermines healthy psychosocial development that would otherwise contribute to a child's future prospects in life.

Risk factors are known to compound their effects (Sameroff, Gutman, \& Peck, 2003). The pervasive nature of labour in a child's life, compromising so many different aspects of children's well-being, means that there can be long-term debilitation in physical, intellectual and social functioning. Risks that compound over time change growth trajectories. A comprehensive review of the literature, however, shows evidence of both positive and negative effects from children's work experiences. In Tables 1, 2 and 3 we have summarized research findings from a survey of the literature, organizing the results into three categories: structural/systemic, relational, and personal risks. In each case, the literature provides evidence of complex outcomes for children.

Table 1

Structural/Systemic Risks and Potential Negative and Positive Consequences Associated with Children's Labour/ Children's Work

\begin{tabular}{llll}
\hline Type of Risk & $\begin{array}{l}\text { Risk } \\
\text { Factor }\end{array}$ & $\begin{array}{l}\text { Potential Negative } \\
\text { Consequences to Child }\end{array}$ & $\begin{array}{l}\text { Potential PositiveResearch } \\
\text { Consequences to Child }\end{array}$
\end{tabular}

$\begin{array}{lll}\begin{array}{l}\text { Structural/ } \\ \text { systemic }\end{array} & \begin{array}{l}\text { Low } \\ \text { wages }\end{array} & \begin{array}{l}\text { Difficulties for the } \\ \text { family to sustain } \\ \text { themselves; poor } \\ \text { access to schooling; } \\ \text { malnutrition; low } \\ \text { family income }\end{array}\end{array}$

The labour/work can make possible school attendance; the child's management of his or her own money, despite the low wages, is valued and generates a sense of independence; income generation prevents feelings of powerlessness; children"s work can be associated with family survival; income helps child experience a contribution to family wellbeing and stimulates a sense of cohesion

$\begin{array}{ll}\text { Extreme } & \text { Insufficient family } \\ \text { poverty } & \text { income; shame; } \\ & \text { child feels he or she } \\ \text { must work, work as } \\ \text { obligation to family; } \\ \text { Children's work, } \\ \text { rather than } \\ \text { schooling, can lead } \\ \text { to reproduction of } \\ \text { the same scarce } \\ \text { economic conditions } \\ \text { across generations }\end{array}$

Involvement in labour/work can increase sense of responsibility within the family, by helping increase the family income; collective life orientation, protection of family unit, sense of belonging, feeling useful and safe within the family as a result of the contribution made; work can strengthen forms of intergenerational solidarity; increased access to consumption goods; feeling important in their mother's eyes; stronger emotional ties
Bourdillon (2000); Fachinni, Fassa, Dall'Agnol and Maia (2003); Invernizzi (2003); Kielland and Tovo (2006); Mapedzahama and Bourdillon (2000)

Anyango-Kivuva (2006); AragaoLagergreen (1997); Bourdillon (2000); Campos and Francischini (2003); Facchini, Fassa, Dall'Agnol, and Maia (2003); Hugerland et al. (2007); Invernizzi (2003); Kenny (1997); Libório and Pessoa (2008);

Perez-Carreon (2006); Rubenson (2005); Traczynski (2000) 


\begin{tabular}{|c|c|c|c|}
\hline $\begin{array}{l}\text { Exposure } \\
\text { to } \\
\text { hazardous } \\
\text { materials } \\
\text { andun- } \\
\text { healthy } \\
\text { substances } \\
\text { (pesticides/ } \\
\text { dangerous } \\
\text { machinery) } \\
\text { and } \\
\text { accidents }\end{array}$ & $\begin{array}{l}\text { Diseases, } \\
\text { disabilities; damage } \\
\text { to nervous system; } \\
\text { over the long-term } \\
\text { can lead to cognitive } \\
\text { malfunctioning; } \\
\text { malnutrition; } \\
\text { infertility; cuts, } \\
\text { amputation, sores } \\
\text { that go untreated } \\
\text { leading to lethal } \\
\text { infections }\end{array}$ & & $\begin{array}{l}\text { Forastieri (1997); } \\
\text { Kielland and Tovo } \\
\text { (2006); Moshin } \\
\text { (2002); Traczynski } \\
\text { (2000); Woodhead } \\
\text { (2004) }\end{array}$ \\
\hline $\begin{array}{l}\text { Large } \\
\text { workload }\end{array}$ & $\begin{array}{l}\text { Long-term health } \\
\text { problems; } \\
\text { insufficient } \\
\text { physiological } \\
\text { development; } \\
\text { skeletal } \\
\text { malformation; } \\
\text { chronic pain } \\
\text { and disability }\end{array}$ & & $\begin{array}{l}\text { Forastieri (1997); } \\
\text { Kielland and Tovo } \\
(2006) \text {; Woodhead } \\
(2004)\end{array}$ \\
\hline $\begin{array}{l}\text { Full-time } \\
\text { work }\end{array}$ & $\begin{array}{l}\text { Reduced time for } \\
\text { play, leisure and } \\
\text { peer relationships; } \\
\text { lack of resting can } \\
\text { lead to prolonged } \\
\text { illness, additional } \\
\text { infections }\end{array}$ & & $\begin{array}{l}\text { Forastieri (1997); } \\
\text { Kielland and Tovo } \\
(2006)\end{array}$ \\
\hline $\begin{array}{l}\text { Exposure } \\
\text { to } \\
\text { addictive } \\
\text { products }\end{array}$ & $\begin{array}{l}\text { Addiction; short } \\
\text { and long term } \\
\text { health problems; } \\
\text { death }\end{array}$ & & $\begin{array}{l}\text { Amnesty } \\
\text { International } \\
(1999) \text {; Libório } \\
(2003)\end{array}$ \\
\hline $\begin{array}{l}\text { Incompa- } \\
\text { tibility of } \\
\text { work and } \\
\text { school- } \\
\text { demands }\end{array}$ & $\begin{array}{l}\text { Learning difficulties; } \\
\text { fear, anxiety; early } \\
\text { dropout, low grades, } \\
\text { grade repetition; } \\
\text { lower average } \\
\text { income as adults; } \\
\text { work has a negative } \\
\text { and sizable effect } \\
\text { on school outcomes }\end{array}$ & $\begin{array}{l}\text { In less modern communities the skills } \\
\text { taught in schools are irrelevant } \\
\text { or inadequate for the labor market } \\
\text { or farming sector; the learning skills } \\
\text { at home and at work relate to those that } \\
\text { are more available in the future labor } \\
\text { market; apprenticeship; development } \\
\text { of vocational skills }\end{array}$ & $\begin{array}{l}\text { Bourdillon (2000); } \\
\text { Buonomo-Zabaleta } \\
\text { (2007); Campos and } \\
\text { Francischini (2003); } \\
\text { Facchini et al (2003); } \\
\text { Kielland and Tovo } \\
\text { (2006); Offit (2003); } \\
\text { Ridao-Cano (2002); } \\
\text { Siaens (2004); } \\
\text { Woodhead (2004) }\end{array}$ \\
\hline $\begin{array}{l}\text { Exposure } \\
\text { to margi- } \\
\text { nalized } \\
\text { groups } \\
\text { (drug } \\
\text { dealers, } \\
\text { pimps) }\end{array}$ & $\begin{array}{l}\text { Stigma; use of } \\
\text { illicit drugs and } \\
\text { cigarettes; } \\
\text { involvement with } \\
\text { juvenile justice } \\
\text { system }\end{array}$ & $\begin{array}{l}\text { Child learns to defend and protect } \\
\text { him- or herself }\end{array}$ & $\begin{array}{l}\text { Invernizzi (2003); } \\
\text { Libório (2003); } \\
\text { Rubenson (2005) }\end{array}$ \\
\hline
\end{tabular}


Table 2

Relational Risks and Potential Negative and Positive Consequences Associated with Children's Labour/Children's Work

\begin{tabular}{|c|c|c|c|c|}
\hline Type of Risk & $\begin{array}{l}\text { Risk } \\
\text { Factor }\end{array}$ & $\begin{array}{l}\text { Potential Negative } \\
\text { Consequences to Child }\end{array}$ & $\begin{array}{l}\text { Potential Positive } \\
\text { Consequences to Child }\end{array}$ & Research \\
\hline \multirow[t]{4}{*}{ Relational } & $\begin{array}{l}\text { Exposure to } \\
\text { sexual } \\
\text { abuse and } \\
\text { exploitation; } \\
\text { emotional } \\
\text { and } \\
\text { physical } \\
\text { violence } \\
\text { (corporal } \\
\text { punishment); } \\
\text { humiliation; } \\
\text { verbal } \\
\text { violence }\end{array}$ & $\begin{array}{l}\text { Exposure to high risk } \\
\text { lifestyles, sexually } \\
\text { transmitted diseases and } \\
\text { addiction to drugs; } \\
\text { evidence of trauma from } \\
\text { participation; fear and } \\
\text { anxiety, guilt, self-blame; } \\
\text { death, broken bones; } \\
\text { unwanted pregnancy and } \\
\text { abortion; reinforces low } \\
\text { self-esteem; exposure to } \\
\text { physical danger; some } \\
\text { children can become } \\
\text { targets of thieves because } \\
\text { they are unprotected and } \\
\text { usually carrying cash }\end{array}$ & $\begin{array}{l}\text { Dissociating between affection } \\
\text { and sex are important coping } \\
\text { strategies these children use to } \\
\text { face sexual exploitation; } \\
\text { solidarity nets among other } \\
\text { working children }\end{array}$ & $\begin{array}{l}\text { Bass (2004); } \\
\text { Blagbrough (2008); } \\
\text { Jacquemin (2004); } \\
\text { Kielland and Tovo } \\
\text { (2006); Libório, } \\
\text { (2003); Rubenson } \\
\text { (2005); Traczynski } \\
\text { (2000); Treguear } \\
\text { and Carro (1997) }\end{array}$ \\
\hline & $\begin{array}{l}\text { Relationship } \\
\text { with } \\
\text { working } \\
\text { peers }\end{array}$ & $\begin{array}{l}\text { When working children } \\
\text { face social isolation from } \\
\text { school-attending peers, } \\
\text { they have few } \\
\text { opportunities for } \\
\text { socialization and } \\
\text { establishing supportive } \\
\text { and protective social } \\
\text { networks }\end{array}$ & $\begin{array}{l}\text { In some labour/work settings, } \\
\text { friendship can be found with other } \\
\text { working children; development } \\
\text { of social organizations, networks } \\
\text { of protection, and reticulations } \\
\text { of support designed to ensure } \\
\text { a common welfare; children find } \\
\text { creative resources to entertain } \\
\text { themselves; working children } \\
\text { often show tenderness and } \\
\text { playfulness with friends }\end{array}$ & $\begin{array}{l}\text { Cruz and Assunção } \\
\text { (2008); Kovats- } \\
\text { Bernat (2001); } \\
\text { Libório (2003); } \\
\text { Traczynski (2000); } \\
\text { Tum (2006) }\end{array}$ \\
\hline & Stigma & $\begin{array}{l}\text { Feelings of rejection, } \\
\text { discrimination, } \\
\text { segregation and exclusion }\end{array}$ & $\begin{array}{l}\text { Solidarity networks are created } \\
\text { with other exploited people }\end{array}$ & $\begin{array}{l}\text { Gomes (1996); } \\
\text { Libório (2003) }\end{array}$ \\
\hline & $\begin{array}{l}\text { Breakdown } \\
\text { of social } \\
\text { networks } \\
\text { (family and } \\
\text { community) }\end{array}$ & $\begin{array}{l}\text { Feelings of abandonment } \\
\text { and lack of protection; } \\
\text { little time spent with } \\
\text { family; some children can } \\
\text { suffer from loneliness and a } \\
\text { lack of their families' } \\
\text { emotional support }\end{array}$ & $\begin{array}{l}\text { Self-respect, when child feels that } \\
\text { he or she has learned to care for } \\
\text { him- or herself; development of } \\
\text { strategies for protection through } \\
\text { supportive networks; for some } \\
\text { working children the ties to their } \\
\text { home are increased as a result of } \\
\text { the income they bring from their } \\
\text { work, avoidance of domestic } \\
\text { violence; in some rural } \\
\text { communities, children's work is } \\
\text { valued and seen as a participative } \\
\text { activity in family life }\end{array}$ & $\begin{array}{l}\text { Bourdillon (2000); } \\
\text { Cruz and Assunção } \\
\text { (2008); Huggins } \\
\text { and Rodrigues } \\
\text { (2004); Invernizzi } \\
\text { (2003); Traczynski } \\
(2000)\end{array}$ \\
\hline
\end{tabular}


Libório, R. M. C. \& Ungar, M. (2010). Children's Labour as a Risky Pathways to Resilience: Children's Growth in Contexts of Poor Resources.

Table 3

Personal Risks and Potential Negative and Positive Consequences Associated with Children's Labour/Children's Work

\begin{tabular}{|c|c|c|c|c|}
\hline Type of Risk & $\begin{array}{l}\text { Risk } \\
\text { Factor }\end{array}$ & $\begin{array}{l}\text { Potential Negative } \\
\text { Consequences to Child }\end{array}$ & $\begin{array}{l}\text { Potential Positive } \\
\text { Consequences to Child }\end{array}$ & Research \\
\hline \multirow[t]{4}{*}{ Personal } & $\begin{array}{l}\text { Threats to } \\
\text { self-concept }\end{array}$ & $\begin{array}{l}\text { Low self-concept; } \\
\text { child is not } \\
\text { unconditionally } \\
\text { valued }\end{array}$ & $\begin{array}{l}\text { Labour/work can bring positive social } \\
\text { recognition and become the core } \\
\text { component of a powerful identity; the } \\
\text { child feels like a valued contributor } \\
\text { to his or her family's welfare }\end{array}$ & $\begin{array}{l}\text { Invernizzi (2003); } \\
\text { Kielland and } \\
\text { Tovo (2006); } \\
\text { Woodhead (2004) }\end{array}$ \\
\hline & $\begin{array}{l}\text { Threats to } \\
\text { self-esteem }\end{array}$ & $\begin{array}{l}\text { Low self-esteem and } \\
\text { self-efficacy when } \\
\text { labour/work is } \\
\text { undervalued by } \\
\text { family or community }\end{array}$ & $\begin{array}{l}\text { Development of confidence and } \\
\text { courage and increased ability to } \\
\text { maneuver more successfully in the } \\
\text { social and physical environment; sense } \\
\text { of independence and responsibility; } \\
\text { pride for the contribution made to } \\
\text { family income; better coping skills } \\
\text { during difficult situations; self-reliant; } \\
\text { feelings of dignity understood as } \\
\text { taking on economic responsibilities } \\
\text { and contributing to family well-being; } \\
\text { greater autonomy; strengthened social } \\
\text { status; self-esteem can improve if the } \\
\text { work activities are appreciated }\end{array}$ & $\begin{array}{l}\text { Aitken, Estrada, } \\
\text { Jennings, and } \\
\text { Aguirre, (2006); } \\
\text { Bourdillon (2000); } \\
\text { Hugerland et al. } \\
\text { (2007); Kielland } \\
\text { and Tovo (2006); } \\
\text { Li (2007); Perez- } \\
\text { Carreon (2006); } \\
\text { Rubenson (2005); } \\
\text { Traczynski (2000); } \\
\text { Tum (2006) }\end{array}$ \\
\hline & $\begin{array}{l}\text { Lack of } \\
\text { power }\end{array}$ & $\begin{array}{l}\text { Sense of useless; } \\
\text { atmosphere of } \\
\text { obedience and } \\
\text { subordination, lack } \\
\text { of freedom, of } \\
\text { relationship with } \\
\text { families and peers, } \\
\text { isolation and feelings } \\
\text { of inferiority }\end{array}$ & $\begin{array}{l}\text { Some children self-recruitment in war } \\
\text { looking for stability and protection; } \\
\text { some children may decide join armed } \\
\text { forces out of hunger and frustration, or } \\
\text { looking for a glamour of soldier's live, } \\
\text { as a possible way to assert their } \\
\text { manhood or as a romanticized seek for } \\
\text { freedom and power (agency); children } \\
\text { working in self-employment activities } \\
\text { can strengthen their social status and } \\
\text { encourage girls and boys to play an } \\
\text { active role in society }\end{array}$ & $\begin{array}{l}\text { Baldwin (2006); } \\
\text { Hugerland et al. } \\
(2007) ; \text { Jacquemin } \\
\text { (2004); Kielland } \\
\text { and Tovo (2006); } \\
\text { Liebel (1998, } \\
\text { 2004); Maulden } \\
\text { (2007) }\end{array}$ \\
\hline & Monotony & $\begin{array}{l}\text { Sadness, apathy and } \\
\text { discouragement }\end{array}$ & & $\begin{array}{l}\text { Campos and } \\
\text { Francischini } \\
(2003)\end{array}$ \\
\hline
\end{tabular}

As well-documented by the studies cited in Tables 1,2 and 3 , there are also a great many benefits to children despite the risks posed by their labour and work. The research which supports this argument is largely phenomenological and is ideally suited to avoiding adultocentric bias in the way children co-construct their experiences of work and labour. Whereas for some children, labour or work could be seen as meaningless, for others it has been shown to be a central dimension of their identity (Woodhead, 2004), as well as foundational to their acquiring structural, relational and personal resources. In such contexts, labour and work become atypical pathways that children resolve the seven tensions in their lives and achieve at least a modicum of resilience amid adversity. Specifically, the research suggests that for some working children, when there are no other valued and available alternatives, their activities secures for them: (a) a positive identity (Bourdillon 2000; Hugerland et al., 2007; Li, 2007; Rubenson, 2005), (b) secure relationships (Huggins \& Rodrigues, 2004; Invernizzi, 
2003; Kovats-Bernat, 2001; Libório, 2003; Tum, 2006), (c) access to material resources such as money and shelter (Anyango-Kivuva, 2006; Cortes \& Buchanan, 2007; Kielland \& Tovo, 2006; Libório, 2003; Libório \& Pessoa, 2008), (d) social cohesion, such as feeling that they belong in their families and communities (AnyangoKivuva, 2006; Bass, 2004; Montgomery, 1998), (e) power and control, as in the ability to effect change in one's social and psysical envirornment (Baldwin, 2006; Hugerland et al., 2007; Liebel, 2004; Maulden, 2007; Perez-Carreon, 2006), (f) social justice when understood as security of person and future work opportunities (Aitken et al., 2006; Aragao-Lagergreen, 1997; Rubenson, 2005), and $(\mathrm{g})$ cultural adherence when work is seen as something valued by children's broader community (Hugerland et al., 2007; Kielland \& Tovo, 2006; Liebel, 2004; Montgo-mery, 1998).

\section{Implications for Intervention}

There is a risk to children's identity if labour and work are unilaterally disallowed (Woodhead, 1999). Based on our summary of the evidence presented above, if labour and work are to end, it is important children have a say in the design of the interventions that will affect them and the alternatives they are offered to their roles as child soldiers, sex workers, agricultural workers or even selfemployed individuals within the informal economy (Aitken et al., 2006; M. Leonard, 2004; Shepler, 2005). Interventions are more likely to fit children's needs when they are conceived holistically, with childhood understood from a multidisciplinary point of view that combines culture, economics, language, health and social services, all in accordance with children's rights and their need for social status (Nieuwenhuys, 2008). A first step must be to challenge the essentializing discourse concerning children which presumes they need only protection and not the opportunities to make a contribution.

Efforts to legislate protections against work (which can lead to the experience of contribution) will only be advantageous if (a) they are restricted to prohibiting only the most exploitive forms of labour, and (b) if working children have a voice in the decisions affecting them. We agree with Nieuwenhuys (2008) that "limiting our understanding of children's rights to legal codes, however widely endorsed, would severely limit, not increase, both children`s entitlements and our understanding of children`s subjectivity in the making of both culture and childhood" (p. 8). Such an approach does not overlook the fact that some forms of child labour and work are oppressive of thousands of children and the result of inadequate and unfair political and economic policies that promotes high rates of poverty and social exclusion. At the same time we understand that the fight against these economic and political forces is complex. In the meantime, even as we help children to work safely and in less exploitive settings, addressing structural and cultural inequalities that lead to the abuse of children as workers is necessary if we are to create work experiences that help children resolve in safe ways the seven tensions they must balance in order to experience resilience.

Children's own social organizations in many countries in Latin America, Asia and Africa may be a useful vehicle to begin this process of engagement with political elites in an effort to create appropriate conditions for children to make a contribution (Liebel, 1998, 2004, 2007a, 2007b). For example, the Movimiento Latinoamericano y del Caribe de ninos, ninas y adolescentes trabajadores (2008) has been working since the 1980s to ensure children's participations in negotiations for personal, social and financial resources that contribute to their well-being. As Liebel (2007a) explains, these voices for children offer a praxis of solidarity among children, helping them train for further qualifications and increasing the likelihood of them finding employment later. They have also been a force for creating alternatives to exploitive labour, such as "self-sustaining economic projects" (p. 281), impacting legislation (as has occurred in Brazil and Peru), decreasing discrimination against children who work, enhancing children's respectful treatment by police, and securing children access to health services. Such examples are indicative of what will need to occur if children are to be saved from exploitation without their access to resources that sustain resilience being denied.

\section{References}

Aitken, S., Estrada, S. L., Jennings, J., \& Aguirre, L. M. (2006). Reproducing life and labour: Global processes and working children in Tijuana, Mexico. Childhood, 13(3), 365-387.

Amnesty International. (1999). In the fire line: War and children's rights. London: Author.

Annan, J. (2007). Self-appraisal, social support, and connectedness as protective factors for youth associated with fighting forces in northern Uganda. Unpublished doctoral dissertation, Indiana University, IA.

Anyango-Kivuva, L. (2006). The forgotten poor: Problematizing policies of children's work and schooling in Kenya. Unpublished doctoral dissertation, University of Pittsburg, PA.

Aragao-Lagergreen, A. (1997). Working children in the informal sector in Managua. Unpublished doctoral dissertation, Upsala Universitet, Sweden.

Baldwin, H. (2006). Fighting to survive in Rwanda: War, agency and victimhood. Unpublished doctoral dissertation, Boston College, MA.

Bass, L. E. (2004). Child labor in sub-Saharan Africa. Boulder, CO: Lynne-Reinner.

Berge, M. V. D. (2007). Working children's movements in Peru. Amsterdan, Netherlands: IREWOC.

Blagbrough, J. (2008). Child domestic labour: A modern form of slavery. Children and Society, 22, 179-190.

Botelho, A. P., Silva, S. L. F., Kassab, M. J., \& Leite, L. C. (2008). Meninos de rua: Desafiliados em busca de saúde mental. Psicologia em Estudo, 13(2), 361-370.

Bourdillon, M. (2000). Earning a life: Working children in Zimbabwe. Harare, Zimbabwe: Weaver Press. 
Libório, R. M. C. \& Ungar, M. (2010). Children's Labour as a Risky Pathways to Resilience: Children's Growth in Contexts of Poor Resources.

Bourdillon, M. (2006). Children and work: A review of current literature and debates. Development and Change, 37(6), 1201-1226.

Buonomo-Zabaleta, M. (2007). A dynamic analysis of the effects of child labor on educational attainments in Nicaragua. Unpublished doctoral dissertation, The George Washington University, Washington, DC.

Campos, H. R., \& Francischini, R. (2003). Trabalho infantil produtivo e desenvolvimento humano. Psicologia em Estudo, 8(1), 119-129.

Cortes, L., \& Buchanan, M. J. (2007). The experience of Columbian child soldiers from a resilience perspective. International Journal for the Advancement of Counselling, 29(1), 43-55.

Cruz, M. N. A., \& Assunção, A. A. (2008). Estrutura e organização do trabalho infantil em situação de rua em Belo Horizonte, MG, Brasil. Saúde e Sociedade (São Paulo), 17(1), 131-142.

Facchini, L. A., Fassa, A. G., Dall'Agnol, M., \& Maia, M. F. S. (2003). Trabalho infantil em Pelotas: Perfil ocupacional e contribuição à economia. Ciência e Saúde Coletiva, 8(4), 953-961.

Forastieri, V. (1997). Children at work: Health and safety risks. Geneva, Switzerland: International Labour Office.

Gomes, R. (1996). O corpo da rua e o corpo na rua: A prostituição infantil feminina em questão. São Paulo, SP: Unimarco.

Howe, R. B. (2007). Introduction: A question of commitment. In R. B. Howe \& K. Covell (Eds.), A question of commitment: Children's rights in Canada (pp. 1-20). Waterloo, ON: WLU Press.

Huggins, M. K., \& Rodrigues, S. (2004). Kids working at Paulista Avenue. Childhood, 11(4), 495-514.

Hugerland, B., Liebel, M., Lisecke, A., \& Wihstutz, A. (2007). Paths to participatory autonomy: The meanings of work for children in Germany. Childhood, 14(2), 257-277.

International Union of Anthropological and Ethnological Sciences. (2002). Studies of Integrated Holistic Programmes with Children and Youth: Child labour in Nepal. New York: Author.

International Labour Organization. (1999). Convention No 182. Retrieved May 5, 2008 from http://www.un.org/children/ conflict/keydocuments/english/iloconvention1828.html

Invernizzi, A. (2003). Street working children and adolescents in Lima: Work as an agent of socialization. Childhood, 10(3), 319-341.

Invernizzi, A., \& Tome, S. (2007). O trabalho de adolescentes no Algarve: Um estudo sobre suas motivações, organização familiar e práticas de socialização. Análise Social, 42(184), 875-898.

Jacquemin, M. Y. (2004). Children's domestic work in Abidjan, Cote D'Ivoire: The petites bonnes have the floor. Childhood, 11(3), 383-397.

Kenny, M. L. (1997). Hidden heads of households: Child labor in Northeast Brazil. Unpublished doctoral dissertation, Columbia University, New York, NY.

Kidd, S., \& Davidson, L. (2007). You have to adapt because you have no other choice: The histories of strength and resilience of 208 homeless youth in New York City and Toronto. Journal of Community Psychology, 35(2), 219-238.

Kielland, A., \& Tovo, M. (2006). Children at work: Child labor practice in Africa. Boulder, CO: Lynne.
Kovats-Bernat, J. C. (2001). The impact of poverty, violence and state repression on cultural identity and social agency of street children. Unpublished doctoral dissertation, Temple University, Philadelphia, PA.

Leonard, M. (2004). Children's view on children's rights to work: Reflections from Belfast. Childhood, 11(1), 45-61.

Leonard, P. (1997). Postmodern welfare: Reconstructing an emancipatory project. Thousand Oaks, CA: Sage.

Lesko, N. (2001). Act your age: A cultural construction of adolescence. New York: Routledge Falmer.

Li, X. F. (2007). Let the children speak: Case study of lived experience in a reform school in Wuhan and its implication to police on street children. Unpublished doctoral dissertation, Hong Kong Polytechinic University, Hong Kong.

Libório, R. M. C. (2003). Desvendando vozes silenciadas: Adolescentes em situação de exploração sexual. Unpublished doctoral dissertation, Universidade de São Paulo, SP.

Libório, R. M. C., \& Pessoa, A. S. G. (2008, June). Crianças, adolescentes e trabalho: Caracterização e atribuição de significado. Paper presented at III Simpósio Internacional sobre Juventude Brasileira no Mundo Contemporaneo: Desafios e Perspectivas, Goiânia, GO.

Liebel, M. (1998). When children organize and want to work. Retrieved July 19, 2008 from http://www.envio.org.ni/articulo/1330

Liebel, M. (2004). A will of their own: Cross cultural perspectives on working children. London: Zed Books.

Liebel, M. (2007a). Working children as social subjects: The contribution of working children's organizations to social transformations. Childhood, 10(3), 265-285.

Liebel, M. (2007b). Paternalism, participation and children's protagonism. Children, Youth and Envirornments, 17(2), 56-73.

Mapedzahama, V., \& Bourdillon, M. (2000). Street workers in a Harare suburb. In M. Bourdillon (Ed.), Earning a life: Working children in Zimbabwe (pp. 25-44). Harare, Zimbabwe: Weaver Press.

Martinez, A. M. (2001). Trabajo infantil y subjetividad: una perspectiva necesaria. Estudos de Psicologia, 6(1), 235-244.

Maulden, P. (2007). Former soldiers and sustainable peace processes: Demilitarizing the body, heart and mind. Unpublished doctoral dissertation, George Mason University, Fairfax County, VA.

Mizen, P., Pole, C., \& Bolton, A. (2001). Hidden hands: International perspective on children's work and labour. New York: Routledge Falmer.

Montgomery, H. (1998). Children prostitution and identity: A case study from a tourist resort in Thailand. In K. Kempadoo \& J. Doezema (Eds.), Global sex workers: Rights, resistance and redefinition (pp. 139-150). New York: Routledge.

Moshin, N. (2002). The lost innocence: A perspective on child labour. Pakistan, India: Commonwealth.

Movimiento Latinoamericano y del Caribe de Ninos, Ninas y Adolescentes Trabajadores. (2008). Declaracion de Cachipay del VII Encuentro del Movimiento Latinoamericano y del Caribe de ninos, ninas y adolescentes trabajadores: luchando por el reconocimiento social de la infancia. Retrieved August 10, 2008 from http://molacnats.org/pdf/ english/cachipay_declaration.pdf

Nieuwenhuys, O. (2008). The ethics of children's rights. Childhood, 15(1), 4-11.

Offit, T. A. (2003). Conquistadores de la calle: Child street labor in Guatemala City, Guatemala. Unpublished doctoral dissertation, Talune University, New Orleans, LA. 
Perez-Carreon, J. G. (2006). Street work girls in Mexico City: Pathways to resilience in an adverse world. Unpublished doctoral dissertation, The University of Texas, Austin, TX.

Pinto, M., \& Sarmento, M. J. (1997). As crianças, contextos e identidades. Braga, Portugal: University of Minho Press.

Quart, A. (2006). Hothouse kids: How the pressure to succeed threatens childhood. New York: Penguin.

Ridao-Cano, C. (2002). Child labor and schooling in rural Bangladesh. Unpublished doctoral dissertation, University of Colorado, Boulder, CO.

Rubenson, B. (2005). Working children's experience and their right to health and well-being. Stockholm, Sweden: Karolinska University Press.

Sameroff, A., Gutman, L. M., \& Peck, S. C. (2003). Adaptation among youth facing multiple risks: Prospective research findings. In S. S. Luthar (Ed.), Resilience and vulnerability: Adaptation in the context of childhood adversities (pp. 364391). Cambridge, UK: Cambridge University Press.

Seccombe, K. (2002). "Beating the odds" versus "Changing the odds": Poverty, resilience, and family policy. Journal of Marriage and Family, 64(2), 384-394.

Shepler, S. A. (2005). Conflicted childhood: Fighting over child soldiers in Sierra Leone. Unpublished doctoral dissertation, University of California, Berkley, CA.

Siaens, C. (2004). Education and child labor in Latin America. Unpublished doctoral dissertation, The American University, Washington, DC.

Taylor, C. S., Lerner, R. M., Von Eye, A., Balsano, A. B., Dowling, E. M., Anderson, P. M., et al. (2002). Individual and ecological assts and positive developmental trajectories among gang and community-based organization youth. In R. M. Lerner, C. S. Taylor, \& A. Von Eye (Eds.), Pathways to positive development among diverse youth (pp. 57-72). New York: Jossey-Bass.

Traczynski, E. E. (2000). The problem of been a poor children in urban Bolivia: All work and no play. Unpublished master's thesis, Simon Fraser University, Vancouver, Canada.

Treguear, T., \& Carro, C. (1997). Niñas y adolescentes prostituidas: silencio social y violación de derechos. San Jose, Costa Rica: United Nations Children's Fund.

Tum, T. C. (2006). The street children phenomenon: A qualitative study on how street children survive in Eldoret, Kenya. Unpublished doctoral dissertation, University of Denver, CO.

Ungar, M. (2004). A constructionist discourse on resilience: Multiple contexts, multiple realities among at-risk children and youth. Youth and Society, 35(3), 341-365.

Ungar, M. (2005). Pathways to resilience among children in child welfare, corrections, mental health and educational settings: Navigation and negotiation. Child and Youth Care Forum 34(6), 423-444.

Ungar, M. (2008). Resilience across cultures. British Journal of Social Work, 38(2), 218-235.

Ungar, M., Brown, M., Liebenberg, L., Othman, R., Kwong, W. M., Armstrong, M., et al. (2007). Unique pathways to resilience across cultures. Adolescence, 42(166), 287-310.

United Nations. (1990). Convention on the Rights of the Child. Retrieved May 10, 2008 from http://www2.ohchr.org/english/ law/pdf/crc.pdf

Woodhead, M. (1999). Combating child labour: Listen to what children say. Childhood, 6(1), 27-49.

Woodhead, M. (2004). Psychosocial impacts of child work: A framework for research, monitoring and intervention. The International Journal of Children's Rights, 12, 321-377.

Recebido: 23/12/2008

$1^{a}$ revisão: $11 / 05 / 2009$ Aceite final: 11/05/2009 